\title{
Et regelverk fullt av smutthull - legenes reseptrett i forbudstiden 1916-26
}

\author{
BAKGRUNN I Norge var det forbud mot omsetning av brennevin 1916-26 og hetvin 1917-23. \\ Denne perioden kalles gjerne forbudstiden. Alkoholforbruket gikk noe ned, men prisen var \\ høy: økt smugling, hjemmebrenning og reseptmisbruk. Det siste skyldtes legenes eksklu- \\ sive rett til å skrive ut alkohol på resept, noe som av enkelte leger ble misbrukt til egen \\ vinning.
}

KUNNSKAPSGRUNNLAG Artikkelen er basert på en gjennomgang av stortingsforhandlingene som omhandler reseptforskrivning i perioden 1916-26, samt artikler om alkoholspørsmålet i Tidsskrift for Den norske lægeforening i samme periode.

RESULTATER Myndighetene forsøkte med et stadig strengere regelverk å demme opp for virksomheten til de såkalte brennevinsdoktorene. Restriksjoner og kontroll av reseptretten var imidlertid lite effektivt, bl.a. fordi legenes rettigheter sto sterkt. Sammen med svakheter ved lovverket gjorde dette det vanskelig å rettsforfølge leger som skrev ut resepter i stor stil. Misbruket nådde sitt klimaks i 1923. Først med en reseptlov som trådte i kraft 1. mars 1924, fikk myndighetene kontroll på reseptmisbruket. Da gikk salget av brennevin på legeresept sterkt tilbake.

FORTOLKNING Reseptforskrivningen av brennevin kom etter hvert ut av kontroll, og myndighetenes stadig nye kontrolltiltak var utilstrekkelige. Da reseptloven omsider ble vedtatt etter tre fors $ø \mathrm{k}$ i Stortinget, var tiden i realiteten ute for brennevinsforbudet.

Striden om alkoholforbudet dominerte det politiske liv i Norge fra slutten av den første verdenskrig og i nærmere ti år fremover. Den kostet tre regjeringer livet, fikk avgjørende innflytelse på to stortingsvalg, avstedkom to folkeavstemninger og den fylte avisene og ble diskutert blant folk med større heftighet enn noe annet spørsmål siden unionsstriden (1).

Men spørsmålet om forbud mot brennevin var ikke nytt. Gjennom deler av 1700-tallet og tidlig på 1800-tallet hadde det vært forbud mot produksjon av brennevin. Liberaliseringen av retten til tilvirkning av brennevin på bygdene fra 1816 førte til en brennevinsflom uten sidestykke i norsk historie (2) og ga støtet til danningen av den organiserte avholdsbevegelsen i 1840-årene. Etter århundreskiftet ble det klart for stadig flere at industrialiseringen og den sterke tilflytningen til byene førte med seg økt misbruk av alkohol og derav store sosiale problemer. Kampen mot alkoholen som samfunnsonde, som en sentral del av sosialpolitikken, ble en sak som forente radikale venstremenn, fagforeningsledere, arbeiderpartifolk og store deler av den kristne legmannsbevegelsen.

Alkoholsaken er en god illustrasjon på det nye interessefellesskapet mellom medisin og politikk. I 1910 satte Stortinget ned en alkoholkommisjon til bekjempelse av drukkenskapen, ledet av professor i hygiene og bakteriologi Axel Holst (1860-1931) og med legen og avholdsaktivisten Johan Scharffenberg (1869-1965) som et av med- lemmene (3, kap. 5). Hvor sterkt avholdssaken sto, viser det faktum at ved valget i 1915 sikret avholdsfolket seg flertall på Stortinget, riktignok for første og siste gang. Tallet på organiserte avholdsfolk nådde sitt klimaks ved slutten av den første verdenskrig, da mer enn hver tiende norske innbygger sto tilsluttet en eller annen organisasjon som gikk inn for totalavhold.

Det er likevel tvilsomt om det hadde blitt et delforbud mot alkohol her i landet hvis det ikke hadde vært for utbruddet av verdenskrigen sommeren 1914. Nervøsitet og usikkerhet om hvordan krigen ville ramme Norge, førte straks til sterke midlertidige innskrenkninger på mange områder, også $i$ adgangen til omsetning av rusdrikk (3, kap. 7). Myndighetene ville ha kontroll med en potensielt viktig kilde til indre «uroligheter og utskeielser» (4). I tillegg gjorde forsyningssituasjonen det naturlig å innføre forbud mot å brygge øl og lage brennevin av korn og poteter. De nærmeste par årene ble restriksjonene vekselvis lempet på og strammet til igjen. Men så, i 1916, gikk utviklingen $i$ en mer definitiv retning. I løpet av sommeren og høsten økte misbruket av alkohol i påtakelig grad, noe som ga seg merkbare utslag i antall drukkenskapsforseelser. Av frykt for en våt julehøytid innførte regjeringen i desember 1916 totalforbud mot salg av brennevin til nytelsesformål frem til over nyttår. Dette juleforbudet skulle imidlertid komme til å vare til 1. januar 1927. Våren 1917 ble forbudet utvidet til også å gjelde hetvin (sterkvin).

\section{Per Eivind Hem}

per.hem@vikenfiber.no

Solbergliveien 19

Oslo

\section{Erlend Hem}

Tidsskrift for Den norske legeforening

Engelsk oversettelse på www.tidsskriftet.no 
Folk flest aksepterte dette i første omgang, men mot slutten av krigen begynte misnøyen å bre seg.

I denne artikkelen vil vi drøfte tre problemstillinger: Hvilket regelverk for alkoholforskrivning hadde legene å forholde seg til? Uttrykket brennevinsdoktor oppsto relativt tidlig i forbudstiden som betegnelse på leger som beriket seg på å skrive ut mengder av resepter på brennevin og hetvin. Men få leger ble dømt. Hvorfor var det så vanskelig å få disse straffet? Avslutningsvis forsøker vi å forklare hvorfor reseptloven ble så vellykket.

\section{Kunnskapsgrunnlag}

Artikkelen bygger på en analyse av stortingsforhandlinger som omhandler reseptforskrivning (proposisjoner, innstillinger og debatter), og artikler om alkoholspørsmålet i Tidsskrift for Den norske lageforening 1916-26. Om rettsforfølgelsen av legen Anders K. Meyer-Lie har vi benyttet Aftenpostens digitale avisarkiv (5). Legenes holdninger til og praktisering av regelverket er behandlet $i$ en annen artikkel (6).

\section{Et mangelfullt regelverk}

Juleforbudet 1916 hadde gjort unntak for brennevin til medisinsk, teknisk og vitenskapelig bruk, men pga. midlertidigheten ved dette forbudet var det til å begynne med ingen som tenkte på regelverket for forskrivning av alkoholholdige medikamenter.

Dersom brennevin ble ansett som egnet legemiddel i det enkelte tilfellet, kunne legen skrive ut dette på resept $\mathrm{i}$ henhold til en kongelig forordning av 1904 (apotekplakaten). Allerede vinteren 1917 begynte apotekene å klage over at det kom en del mennesker med resepter på alkohol, som ganske sikkert ikke var syke. Disse apotekerne protesterte mot å være nødt til å opptre som brennevinshandlere.

Sosialdepartementets rundskriv av 8. mai 1917 skulle rydde opp i denne resepttrafikken. Det mangelfulle regelverket hadde gjort det enkelt for folk som søkte det sterke og hadde med en velvillig lege å gjøre. Legen kunne i prinsippet utstyre pasienten med en resept på brennevin i hvilke som helst kvanta, og det fantes heller ingen klare grenser for hvor mange ganger det kunne hentes ut alkohol på samme resept.

De nye reglene bestemte at legen nå ikke kunne skrive ut mer enn $3 / 4$ liter (en flaske) brennevin om gangen og av hetvin maks to flasker. Resepten skulle være forsynt med

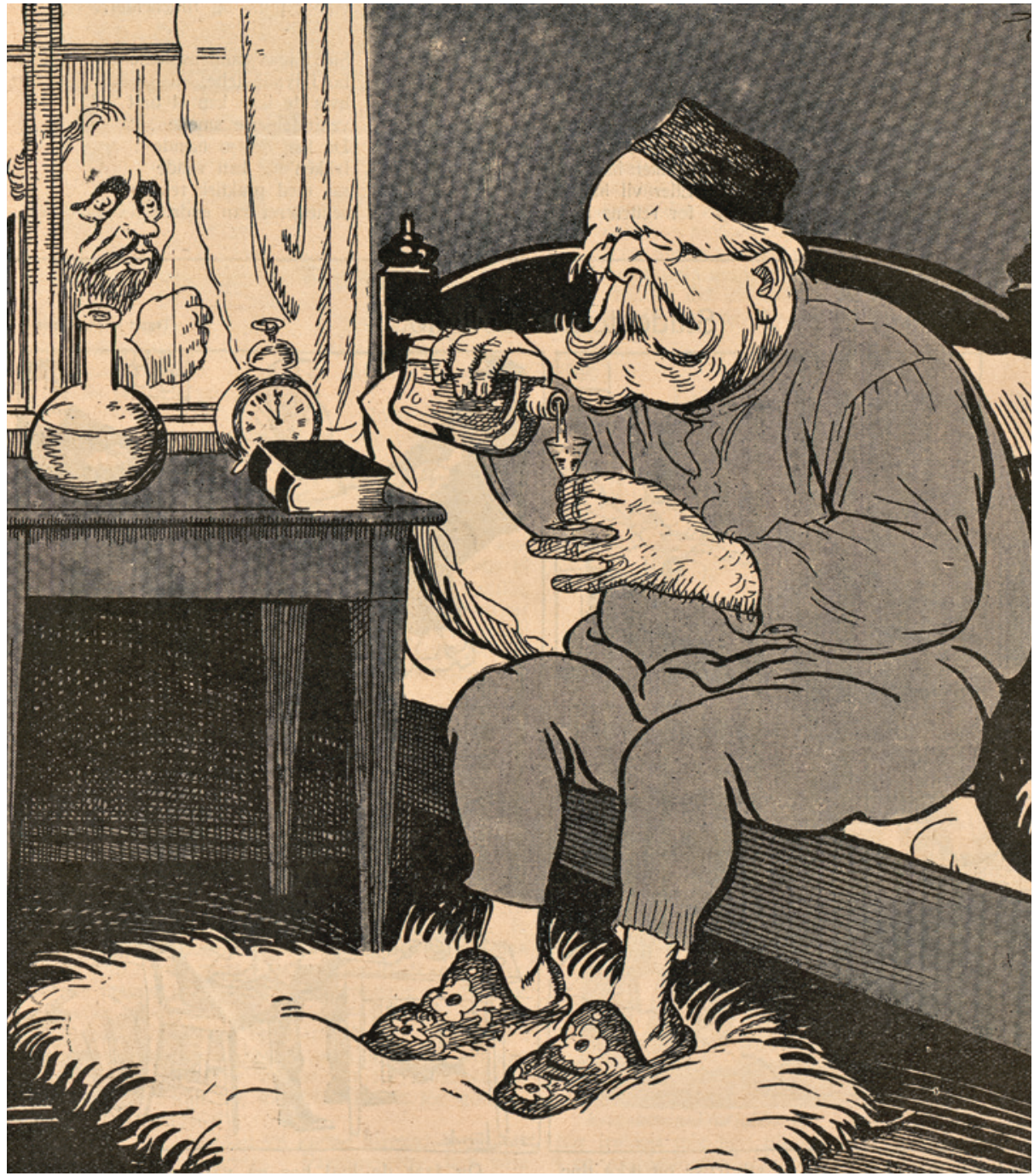

Figur 1 Høsten 1918 ble regjeringen presset til å tillate alle husstander å kjøpe en halv flaske brennevin uten resept. Uttrykket «den løvlandske halvflaske» stammer fra den alkoholliberale kirke- og undervisningsminister Jørgen Løvland (1848-1922), som akkurat da vikarierte for sosialministeren og avholdsmannen Lars Abrahamsen (1855-1921). Her er Løvland karikert av tegneren Jens R. Nilssen (1880-1964) i vittighetsbladet Hvepsen nr. 35/1919. Verk av @ Jens R. Nilssen/BONO

den sykes navn, og det skulle uttrykkelig stå at varen var bestemt til medisinsk bruk. Resepten gjaldt maksimalt for tre ganger. Inntil disse reglene tok til å gjelde våren 1917 , hadde det i praksis vært umulig å kritisere en lege for at han forskrev for store mengder alkohol. Dette ble nå annerledes, og avisene begynte å skrive om misbruk av brennevinsresepter.

Det viste seg imidlertid snart at forskriften fra mai 1917 ikke hadde den tilsiktede effekt. Nye og strengere regler kom i mars 1918, men manglende lovhjemmel gjorde det umulig for sosialminister Lars Abra- hamsen (1855-1921) i Gunnar Knudsens (1848-1928) venstreregjering å gå så langt som han ønsket. Et halvt år senere fikk han derfor endret brennevinsloven, men nye forskrifter kom ikke på plass før i desember 1919. Da hadde den radikale venstremannen Paal Berg (1873-1968) overtatt etter Abrahamsen som statsråd i Sosialdepartementet, og folkeavstemningen i oktober 1919 hadde gitt klart flertall for varig forbud mot salg av brennevin og hetvin som nytelsesmiddel riktignok under forutsetning av at Norge fikk i stand levelige handelsavtaler med vinlandene Spania, Portugal og Frankrike, som 

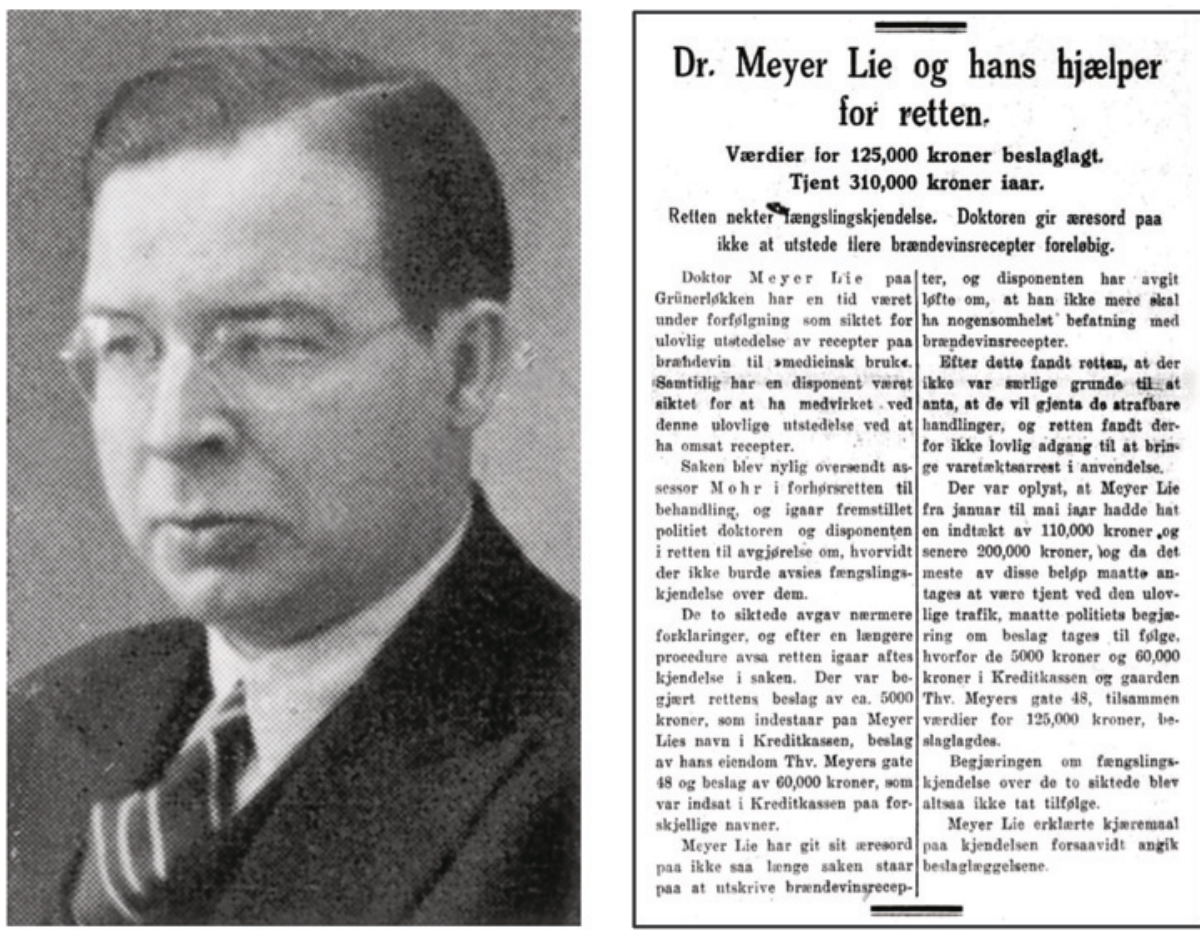

Figur 2 Anders Kornelius Meyer-Lie (1894-1946) var lege på Grünerløkka i Kristiania, og ble stilt for retten etter å ha skrevet ut ca. 38000 brennevinsresepter i 1923. Foto fra Studentene fra 1913 (14). Han ble dømt i byretten, men frifunnet i lagmannsretten. Faksimile fra Aftenposten 13.11.1923

Norge importerte alkohol fra og eksporterte store mengder klippfisk til.

Bergs tilstramning av regelverket før jul 1919 så bra ut på papiret, men heller ikke det virket etter intensjonen. Legene forskrev ikke færre resepter på brennevin i 1920, tvertimot økte forskrivningen betraktelig. Apotekenes omsetning av brennevin ble omtrent fordoblet fra 1921 til 1923, som var et toppår for både spritsmugling og misbruk av brennevinsresepter. Bergs forskrift tettet bare noen av smutthullene. For eksempel skulle resepten såvidt mulig angi hvor ofte medisinen skulle brukes og i hvor store doser. Historikeren Per Fuglum (1924-2008) har pekt på at dette burde ha vært utformet som et påbud (2, s. 430). Det samme gjaldt oppfordringen om at resepten burde være forsynt med legens navnestempel i tillegg til hans (ofte uleselige) navnetrekk. Dermed fikk man ikke bukt med det som lenge hadde vært et omseggripende problem, nemlig forfalskede brennevinsresepter. Det ble heller ikke stilt krav om at resepten skulle opplyse hvilken lidelse brennevinet eller hetvinen var ment for. Og sist men ikke minst hadde legen fremdeles anledning til å skrive ut mer enn det tillatte kvantum når scerlige grunner tilsa det.

Legenes forskrivningsrett hadde vist seg juridisk sett å stå sterkt, og de rettssakene som ble igangsatt mot brennevinsdoktorer dokumenterte at det skulle mye til før en lege risikerte noe. Dette var doktorer og pasienter fullt på det rene med. Frem til 1924 var det bare de mest outrerte eksempler på misbruk som ga en (kortere) fengselsstraff og inndragning av opptjent formue. Pasienten medisin, og om legen ikke skulle miste sin pasient, måtte det være fristende å gi etter for henstillingen. Særlig ille ble det under spanskesyken 1918-19, da kravet om husmedisin var massivt og sterkt følelsesbetont. Senhøsten 1918 ble regjeringen Gunnar Knudsen presset til å tillate alle husstander som et engangstilfelle å kjøpe en halvflaske brennevin uten resept - «den løvlandske halvflaske» (fig 1). Uten et godt lovverk på plass fortsatte utglidningen. Folks holdninger endret seg gradvis, og i årene 1920-23 synes stadig flere mentale sperrer å ha forvitret hos godtfolk mot å be om, og leger mot å forskrive, brennevin i påkommende tilfeller. (dvs. som forebyggende middel)

\section{Behovet for en reseptlov}

Skulle myndighetene få bukt med reseptmisbruket, innså man behovet for en reseptlov som hjemlet de nødvendige tiltak. Et effektivt alternativ til rettsforfølgelse ville være at departementet grep inn i enkeltlegers reseptrett, men for å kunne gjøre det trengtes endringer i lovverket. Dette var mange leger skeptiske til. Selv en så ihuga forbudstilhenger som Johan Scharffenberg talte varmt om legers ukrenkelige reseptrett $(7,8)$. Legenes faglige autonomi hadde røtter langt tilbake, ingen andre skulle kunne legge seg borti, enn si overprøve, den selvfølgelige retten for doktoren til å vurdere hva som var det beste middel til å hjelpe eller kurere den syke. kunne frimodig be legen om en flaske hus-
Noe av det siste Paal Berg gjorde som sosialminister var i juni 1920 å sette ned et sakkyndig utvalg som skulle forberede en generell lov om legers plikter og rettigheter. Det første dette utvalget ble bedt om var imidlertid å lage utkast til en lov om legers alkoholforskrivning (reseptlov). Utvalget var dominert av leger, bl.a. medisinaldirektør Harald Gram (1875-1929) og professorene Edvard Poulsson (1858-1935) og Ragnar Vogt (1870-1943). Det gikk enstemmig inn for at alle over 25 år skulle kunne kjøpe $1 / 2$ flaske brennevin eller en flaske hetvin til husmedisin en gang i kvartalet uten å måtte oppsøke lege, altså en slags rasjonering. Dette var «den eneste effektive maate, hvorpaa man kan komme bort fra de misbruk, som endel læger nu $i$ adskillig grad gjør sig skyldig i» $(9$, s. 4). De første årene forbudet gjaldt var det stadig blitt understreket at det bare var en håndfull leger som misbrukte reseptretten. I 1920-21 var både situasjonen og erkjennelsen en annen. Ved å frita legene for reseptforskrivning av alkohol til forebyggende medisin mente utvalget at det ikke lenger ble så lett å misbruke eller tøye reseptretten. Det foreslo å forby legene å utstede resept på alkohol med mindre de på forsvarlig vis forvisset seg om at det forelå en sykdom som alkohol kunne være virksom mot.

Dette forslaget ble tidlig våren 1921 levert til den konservative regjeringen ledet av Otto B. Halvorsen (1872-1923), som ganske sikkert ville ha gått inn for det. Før hans sosialminister rakk å fremsette en proposisjon kom imidlertid en ny venstreregjering til makten med Otto Blehr (1847-1927) som statsminister og Lars Oftedal (1877-1932) som sosialminister. Den nye regjeringen kunne ikke gå med på et rasjoneringssystem, slik det sakkyndige utvalget hadde foreslått, men holdt på at all alkohol over 12 volumprosent (brennevin og hetvin) fortsatt skulle forskrives av lege. Hovedvekten skulle legges på et hurtigvirkende kontrollapparat. Odelsting og lagting sto kløyvd på midten i september 1921, og det endte med at lovforslaget ble henlagt. Tidligere samme måned hadde imidlertid den samme regjeringen fått flertall for forbudsloven, som innførte varig forbud mot brennevin og hetvin som nytelsesmiddel.

Ny proposisjon om reseptlov ble lagt frem vinteren 1922 av Blehrs regjering. Sosialminister Oftedal hadde ikke forandret syn og gikk på ny inn for at alkohol i påkommende tilfeller ikke skulle fås på annen måte enn ved resept. Legestanden var imidlertid sterk motstander av å lovfeste en slik plikt. Stavanger bys legeforening sendte protest til Stortinget: Legenes oppgave var å hjelpe syke, ikke å utdele brennevin til friske (10). Selv den profilerte avholdsmannen Rasmus Hansson (1859-1934), som var Legeforeningens generalsekretær og medredaktør i Tidsskriftet, mente presset på legene ville 
bli «tifold verre» ved en lovfesting og støttet det sakkyndige utvalgets rasjoneringsforslag. Han trodde regjeringen Blehrs opplegg ville fremelske et stort antall brennevinsleger. Grunnet den sterke motstanden kom heller ikke denne proposisjonen til realitetsbehandling (11).

Vinteren 1923 gikk venstreregjeringen av og ble erstattet av en ny konservativ regjering. Det første som skjedde var at hetvinsforbudet ble opphevet, dernest kom tredje forsøk på å få i stand en reseptlov - nå bare for brennevin (12). Forslaget bygde i hovedsak på opplegget til det sakkyndige utvalget om rasjonering. Reseptloven ble i noe endret form vedtatt høsten 1923 og iverksatt fra 1. mars 1924. Leger skulle ikke lenger forskrive alkohol i påkommende tilfeller, men det skulle heller ikke være anledning til å få kjøpt brennevin til dette formålet. Det betydde i praksis farvel til brennevin som profylaktisk middel mot sykdom.

\section{Brennevinsdoktorer}

Allerede i august 1917 sto den første meldingen i Tidsskriftet om misbruk av reseptretten. En lege i Bergen hadde skrevet ut så mange brennevinsresepter at han denne våren hadde måttet forklare seg for medisinaldirektøren. Rapporten om en Kristianialege som hadde sittet på en bodega og skrevet ut resepter på brennevin til medisinsk bruk for ti kroner per resept, vakte naturlig nok også oppsikt. Det var den frimodige dr. Gustav Michelsen (1862-1926).

Antall brennevinsdoktorer økte år for år. Da Stortinget vinteren 1918 diskuterte brennevinsforskrivning, trakk Johan Castberg (1862-1926) frem det han mente var et grelt eksempel på misbruk av reseptretten - en lege som «bare paa én maaned» hadde skrevet ut 550 resepter, det tilsvarte 6600 på årsbasis (13). I 1921 skrev 21 leger ut 10000 resepter eller mer. I toppåret 1923 var tallet 29. Dette utgjorde ca. $2 \%$ av landets leger. I sjiktet under befant det seg hele 49 doktorer som sto for 5 000-10 000 resepter (2, s. 427), dvs. at mer enn hver 20. lege skrev ut 5000 brennevinsresepter eller mer i 1923 . Selv 5000 resepter betyr 16-17 resepter seks dager i uken året rundt, fratrukket to ukers ferie.

13. november 1923 hadde Aftenposten en artikkel på forsiden om at dr. Anders Kornelius Meyer-Lie (1894-1946), lege på Grünerløkka i Kristiania, en tid hadde vært under etterforskning for reseptsvindel (fig 2) $(14,15)$. Det ble opplyst at han hadde tjent 310000 kroner så langt i 1923 og at verdier for 125000 kroner nå var beslaglagt. Omtrent samtidig ble legen ekskludert fra Legeforeningen (16). Meyer-Lie var ung, bare 30 år, og hadde ikke praktisert mer enn $i$ et par år (17). Da saken mot ham kom opp for Kristiania byrett i juni 1924, brakte Aftenposten daglige referater fra rettsforhandlingene. I retten verserte det en topp ti-liste, og det viste seg at Meyer-Lie i 1923

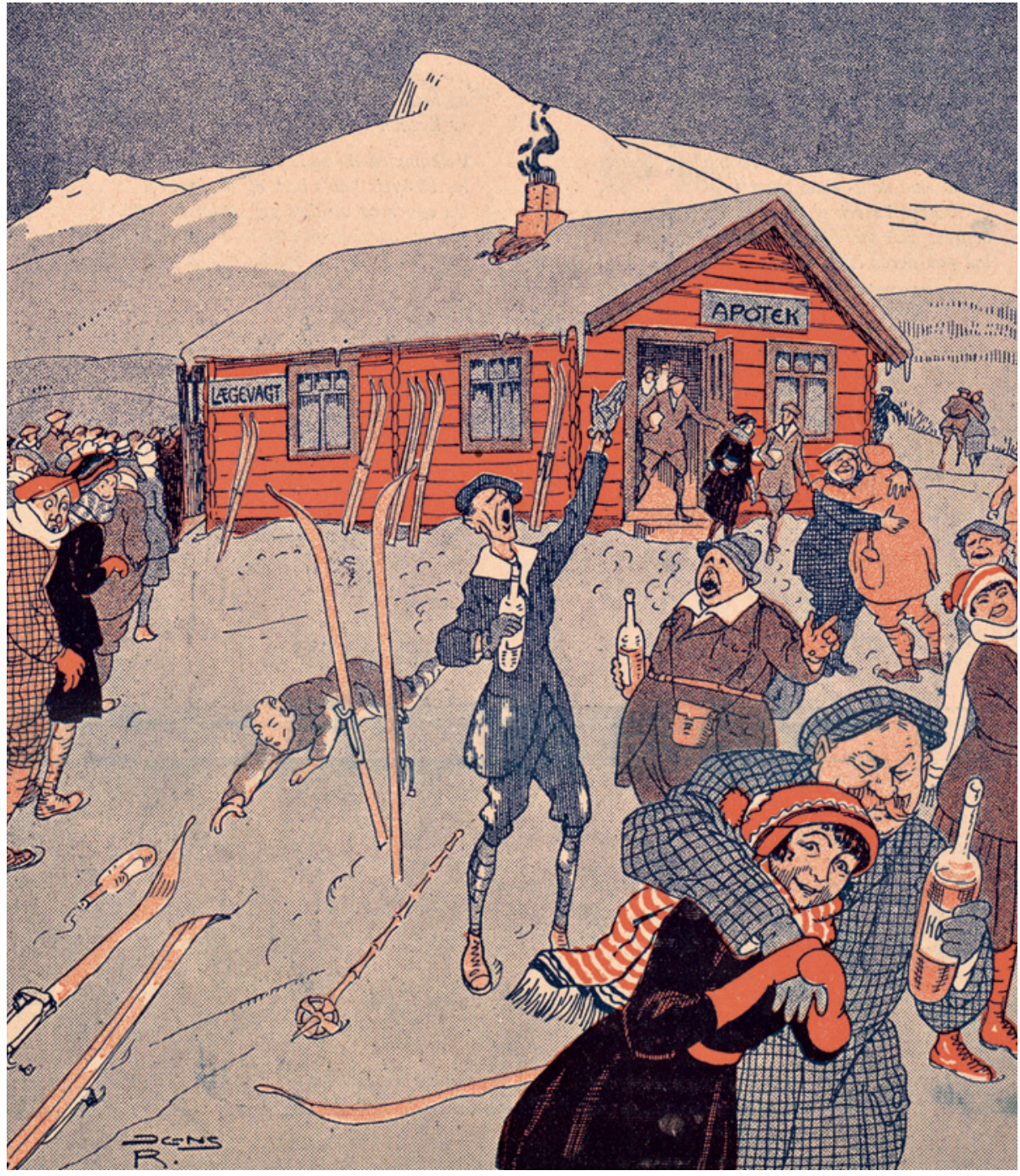

Figur 3 Det var ikke noe klart skille mellom brennevinsdoktorene og vanlige leger. Tøyingen av reseptretten ble stadig verre frem til reseptloven trådte i kraft våren 1924. Her har tegneren Jens R. Nilssen (1880-1964) karikert situasjonen på høyfjellet i påsken i vittighetsbladet Hvepsen nr. 13/1921. Verk av @ Jens R. Nilssen/ BONO

havnet som en god nummer to med ca. 38000 resepter på 90000 flasker brennevin.

Forsvareren prosederte likevel på full frifinnelse: Etter loven var det ikke straffbart å skrive ut resept uten undersøkelse. Forskrivning av brennevin som profylaktisk middel var frem til reseptloven trådte i kraft, slett ikke forbudt. Forsvareren hevdet videre at det ikke fantes bevis på at legen i noe tilfelle hadde visst at brennevinet ville bli benyttet til annet enn medisin. Men det hjalp ikke, Meyer-Lie ble dømt til 60 dagers fengsel og inndragning av 100000 kroner til statskassen. Legen anket, og da saken kom opp for lagmannsretten i november 1924, havnet han igjen på Aftenpostens forsider. Etter tre dagers rettsforhandlinger ble Meyer-Lie frifunnet.

Både $\mathrm{i}$ byrett og lagmannsrett viste forsvareren til en rekke frifinnelsesdommer mot leger som i likhet med Meyer-Lie hadde skrevet ut et stort antall resepter. Mannen på førsteplass, Gustav Michelsen (med 48657 resepter på samvittigheten i 1923), var det ikke engang tatt ut tiltale mot. Det ville selvsagt være galt å dømme Meyer-Lie for det samme som andre leger var blitt frikjent for, hevdet forsvareren. Dette fikk han lite gehør for i byretten, men synspunktet synes å ha blitt tillagt vekt i lagmannsretten. Saken mot Meyer-Lie viser hvor vanskelig det var å få en brennevinsdoktor dømt.

Meyer-Lies forsvarer hadde allerede i byretten påpekt at med den nye reseptloven ville det ikke lenger være mulig for leger å havne i en slik situasjon som MeyerLie - forskrivningsmulighetene var blitt så drastisk begrenset. Derfor burde det ikke vært reist tiltale mot ham, hevdet han. Indirekte beskyldte forsvareren myndighetene for tilstandene frem til 1924. Det var lovgiver som hadde gjort det mulig for leger å forskrive et så stort antall resepter.

Rettssaker mot brennevinsdoktorer etter reseptlovens ikrafttreden synes ikke å ha hatt noe med denne loven å gjøre, men skyldtes den masseforskrivning som skjedde før 1. mars 1924. Hovedårsaken til at det var så vanskelig å få leger dømt for 
brudd på reseptretten etter den tidligere lovgivningen, var vanskene med å bevise at forskrivningen var ulovlig (fig 3). Vel var antall resepter voldsomt høyt, men det var ikke dermed sagt at legen ikke hadde dekning for sin forskrivningspraksis. Selv mente han alltid det, i retten. Når de aller fleste reseptene gjaldt i påkommende tilfeller, var det ikke lett for retten å «overprøve» legens avgjørelse. At reseptretten sto så sterkt, synes også å ha bidratt til vanskene med å få rettskraftige dommer på brennevinsdoktorene.

\section{Forbudstiden på hell}

Etter at reseptloven trådte i kraft 1. mars 1924, gikk salget av brennevin på legeresept sterkt tilbake. Halvåret fra mars til august 1924 sank det fra 448000 liter til 71000 liter sammenliknet med tilsvarende periode i 1923, altså til en seksdel. De tre siste forbudsårene, 1924-26, var legers forskrivning av alkohol ikke lenger noe problem. Antall forskrivninger forble lavt i forhold til toppnivået i 1923. Hva besto det lykkelige grep i?

En vesentlig forklaring må tilskrives reseptlovens beskaffenhet og de betydelig økte ressursene som ble satt inn i kontrollarbeidet. Reseptloven hadde gjort kort prosess med brennevin som husmedisin. Når det nå bare kunne forskrives alkohol ved sykdom, hadde legene vesentlig mindre mulighet til å tøye grensene, til å misbruke reseptretten. I Tidsskriftet kom det fra legehold - forunderlig nok - ikke på trykk noen kommentarer til reseptloven og dens virkninger, bortsett fra rent faktiske opplysninger om utviklingen i reseptforskrivningen.

For kontrollørene ble arbeidet mer overkommelig etter at reseptloven trådte $\mathrm{i}$ kraft. Det skyldtes både at det ble mindre å kontrollere og at det altså ble satt inn mer ressurser til formålet. I Medisinaldirektoratet ble det etablert en egen organisatorisk enhet kalt Reseptkontrollen, og det ble opprettet et sakkyndig legeråd som bl.a. skulle ta stilling til og gi råd om innskrenkning i og eventuelt suspensjon av legers reseptrett. Legene fikk tilsendt reseptkuponger fra myndighetene etter innmeldt behov, med 100 resepter i hver kupong. Det ga direktoratet og departementet mulighet til å kikke kupongivrige leger i kortene på et tidlig tidspunkt. Samtidig ga loven departementet adgang til å gripe inn mot leger som drev en kritikkverdig forskrivningspraksis. Tidligere hadde medisinaldirektøren kun hatt anledning til å gi muntlige, nærmest underhånden advarsler, men noen sanksjonsrett hadde han ikke. Nå kunne administrasjonen iverksette innskrenkninger i reseptretten, men var fremdeles avskåret fra å suspen- dere legers rett til å skrive ut slike resepter. Det ble det mulig å gjøre ved kongelig resolusjon, altså av regjeringen, men kom først på tale ved så graverende misbruk at det var grunnlag for strafferettslig forfølgelse.

I løpet av reseptlovens første halvår fikk 28 leger merke at myndighetene fulgte med. Departementet påla fire leger innskrenket rett til «inntil videre» å utstede brennevinsresepter, og 18 andre ble bedt om å vise forsiktighet ved sine forskrivninger av brennevin. I statsråd ble det besluttet å frata seks leger retten til å forordne brennevin for en avgrenset tidsperiode (18). Hvor mange leger som ble ekskludert fra Legeforeningen i forbudstiden, er usikkert. Sannsynligvis var det flere enn de ca. ti som eksplisitt er nevnt i Tidsskriftet, men langt færre enn det antallet som var i myndighetenes søkelys.

Mens alle tidligere forsøk på å regulere og kontrollere reseptforskrivningen hadde virket heller dårlig, var altså reseptloven en umiddelbar suksess. Likevel ble forbudet opphevet bare tre år senere, etter at det var blitt holdt rådgivende folkeavstemning om saken. Avviklingen av forbudet hadde sammenheng med flere andre faktorer, ikke minst forholdet til Frankrike, Spania og Portugal. Disse nærmest tvang norske myndigheter til å kjøpe store kvanta brennevin, som bare ble stående på lager. Spritsmuglingen og ikke minst hjemmebrenningen bidro også sterkt til forbudets endelikt.

Hvorvidt det hadde hatt noe å si for forbudets beståen om reseptloven hadde kommet på plass 2-3 år tidligere, er tvilsomt. Men det kan ikke være diskutabelt at den voldsomme økningen i forskrivning av brennevin i begynnelsen av 1920-årene ikke hadde vært mulig med reseptloven.

\section{Avslutning}

Det er påfallende at det varte så lenge før en reseptlov kom på plass. Myndighetene ble tidlig klar over at lovhjemmelen for å stille krav til legenes forskrivning og å føre kontroll med praksisen både var tvilsom og mangelfull. Sosialdepartementet ventet med å endre loven fordi det ikke hadde forestilt seg at det ville skli ut i den grad det gjorde. Troen på nye og stadig mer restriktive føringer og kontrolltiltak med utgangspunkt i gjeldende lovgrunnlag virker i ettertid nokså naiv. Man visste ikke hva som skulle til og grep kravene til forskrivning og kontroll for lempelig an. Det var først da respekten for forbudet blant menigmann - og sikkert også blant flertallet av legene - var i ferd med å rakne, at reseptloven endelig ble vedtatt. Selv om reseptmisbruket ble stanset, var brennevinsforbudet da allerede dødsdømt.

\section{Per Eivind Hem (f. 1963)}

er statsviter og har utgitt biografiene Jørgen Løvland: vår første utanriksminister (Samlaget, 2005) og Megleren: Paal Berg, 1873-1968

(Aschehoug, 2012).

Forfatter har fylt ut ICMJE-skjemaet og oppgir ingen interessekonflikter.

\section{Erlend Hem (f. 1970)}

er dr.med. og assisterende sjefredaktør i Tidsskriftet.

Forfatter har fylt ut ICMJE-skjemaet og oppgir ingen interessekonflikter.

\section{Litteratur}

1. Christensen CA. Fra verdenskrig til verdenskrig I: Coldevin A, Dahl T, Schreiner J, red. Vårt folks historie. Bd. 8. Oslo: Aschehoug, 1962: 199.

2. Fuglum P. Brennevinsforbudet i Norge. Trondheim: Tapir, 1995

3. Schrumpf E. Berus eder! Norske drikkekulturer i de siste 200 år. Oslo: Unipax, 2003.

4. Ot.prp. nr. 23 (1917). Om tillæg til lov om salg og skjænkning av brændevin, øl, vin, frugtvin og mjød av 17de mai 1904

5. Aftenpostens digitale avisarkiv. www.aftenposten.no/arkivet/ (8.11.2012)

6. Hem PE, Hem E. «Tør virkelig en læge vove at negte en patient kognak?!»- legenes reseptforskrivning i forbudstiden 1916-26. Tidsskr Nor Lægeforen 2012; 132: 2641-5.

7. Scharffenberg J. Lægernes alkoholforordninger. Trondhjem, 1918: 7-10.

8. Søbye E. En mann fra forgangne århundrer. Overlege Johan Scharffenbergs liv og virke 1869-1965. En arkivstudie. Oslo: Oktober, 2010: 408.

9. Ot.prp. nr. 54 (1921). Om utferdigelse av en lov om brennevin og hetvin til medicinsk bruk.

10. Red. Receptlov-forslaget og Stavangerlægerne. Tidsskr Nor Lægeforen 1922; 42: 242-3.

11. Ot.prp. nr. 14 (1922). Om utferdigelse av en lov om brennevin og het vin til medisinsk bruk.

12. Ot.prp. nr. 32 (1923). Om utferdigelse av en lov om brennevin til medisinsk bruk.

13. Stortingstidende 1918, s. 301

14. Studentene fra 1913. Biografiske opplysninger samlet til 50-års jubileet 1963. Trykt som manuskript. Oslo, 1963: 166-7.

15. Brochmann G. red. Studentene fra 1913. Biografiske oplysninger, artikler til belysning av kullets egenart og statistikk, samlet til 25-års jubileet 1938. Oslo: Bokkomiteen for studentene 1913. 1938: 178.

16. To Kristiania-læger ekskludert for alkoholforskrivning. Tidsskr Nor Lægeforen 1923; 43: 1343-4

17. Larsen $\emptyset$. red. Norges leger. Bd. 5. Oslo: Den norske lægeforening, 1996: 773

18. Sterk nedgang i lægernes forskrivning av brændevin og spiritus, meget mindre for dyrlægernes vedk. Tidsskr Nor Lægeforen 1924; 44: 1070.

Mottatt 17.10. 2012, første revisjon innsendt 5.11. 2012, godkjent 8.11. 2012. Medisinsk redaktør Are Brean. 